\title{
CARTA AO AVALIADOR
}

Caro Avaliador, agradecemos os comentários realizados e encaminhamos, a seguir, a descrição das mudanças realizadas no artigo. Aproveitamos para informá-lo que todas as alterações estão destacadas em vermelho na nova versão do artigo.

Estamos à disposição para esclarecimentos e/ou novas correções no artigo.

Atenciosamente,

Autores.

\section{AVALIADOR A}

Comentário: $\mathrm{O}$ artigo tem como objetivo analisar as relações comerciais entre os países do BRICS (Brasil, Rússia, Índia, China e África do Sul), por grau de intensidade tecnológica, no período 20002014, com ênfase nos produtos primários. Se as relações comerciais serão analisadas por intensidade tecnológica, sugiro retirar "com ênfase nos produtos primários".

- Resposta dos autores: Esta frase foi retirada do Resumo, do Abstract e da Introdução (objetivo geral).

Comentário: O texto apresenta revisão bibliográfica suficiente, porém carece de uma seção de referencial teórico em que se apresentem os modelos teóricos que justifiquem a preocupação pela formação da estrutura produtiva baseada em produtos primários. Sugiro incluir breve discussão.

- Resposta dos autores: O artigo foi reestruturado, sendo incluída a seção 2, que aborda o processo de reprimarização no Brasil. Nesta nova estrutura do artigo, a revisão bibliográfica mencionada na Introdução foi deslocada para a seção 2 e o texto da antiga seção 2 ("BRICS na economia mundial”) foi transferido para a Introdução e para o início da seção 3; a antiga Tabela 1 e o antigo Gráfico 2 foram deslocados para os Anexos; e a antiga Tabela 2 foi deslocada por o início da seção 3 .

Comentário: Na descrição da metodologia poderia esclarecer se a classificação por intensidade tecnológica foi realizada pelo(s) autor(es) ou se foi extraída do sistema já classificado.

- Resposta dos autores: O esclarecimento foi inserido na Introdução. 
Comentário: $\mathrm{Na}$ conclusão a afirmação "O aumento das exportações pode ser justificado pela expansão dos preços e do volume exportado, com ênfase para as importações chinesas" não encontra respaldo no estudo; não há evidências que os preços tenham sido analisados - sugiro o calculo dos índices de preços e de quantum nas análises, de acordo com a metodologia do SECEX.

- Resposta dos autores: Esta parte das conclusões foi reformulada e justificou-se apenas a partir do aumento da demanda chinesa, que foi evidenciada nos estudos empíricos abordados neste estudo. 